\title{
Rapid adaptation of predation resistance in bacteria isolated from a seawater microcosm
}

\author{
P. Mathisen ${ }^{1}$, J. Thelaus ${ }^{2}$, S. Sjöstedt de Luna ${ }^{3}$, A. Andersson ${ }^{1, *}$ \\ ${ }^{1}$ Dept. of Ecology and Environmental Science, Umeå University, 90187 Umeå, Sweden \\ ${ }^{2}$ Division of CBRN Defence and Security, FOI Swedish Defence Research Agency, 90182 Umeå, Sweden \\ ${ }^{3}$ Dept. of Mathematics and Mathematical Statistics, Umeå University, 90187 Umeå, Sweden
}

\begin{abstract}
Bacterial defense against protozoan grazing has been shown to occur in many different bacteria. Predation resistance traits may however be plastic, making bacterial communities resilient or resistant to predation perturbations. We studied the adaptation of predation resistance traits in bacteria isolated from a microcosm experiment. In the initial microcosm experiment the predation pressure on bacteria varied markedly, while changes in the bacterial community composition could not be verified. Seven bacteria were isolated from the microcosm (Micrococcus sp., Rhodobacter sp., Paracoccus sp., Shewanella sp., Rhizobium sp. and 2 unidentified species) and these were repeatedly exposed to high predation by the ciliate Tetrahymena pyriformis. High variations in edibility and rate of adaptation of predation resistance traits were observed among the strains. The initial mortality rate of the different bacterial taxa and the change over time varied by a factor of 7 and 24, respectively. Rhodobacter sp. was already predation resistant at the start of the experiment and did not change much over time, while Micrococcus sp., Paracoccus sp. and Shewanella sp. initially were relatively edible and later developed predation resistance. In conclusion, we show that rapid adaptation of predation resistance traits is common among bacteria in an aquatic microbial community, and that a single test of a bacterium's edibility will in many cases not be enough to fully understand its ecological role, as it will not reveal the potential adaptive response. The results suggest the potential of rapid changes of predation resistance as a mechanism for bacterial communities to be resilient to variations in predation disturbances.
\end{abstract}

KEY WORDS: Bacterial isolates $\cdot$ Predation pressure $\cdot$ Predation resistance $\cdot$ Inedible $\cdot$ Adaptation · Tetrahymena

\section{INTRODUCTION}

In aquatic environments bacteria are exposed to intense predation from viruses, protozoa and other small eukaryotes (Hahn \& Höfle 2001, Weinbauer 2004, Winter et al. 2010, Salcher 2014). Consequently, bacteria have evolved a multitude of different defense strategies to avoid degradation. Commonly described defense mechanisms are changes in morphology (e.g. elongation, aggregation and filament formation), increased growth rate, motility, toxicity, avoidance of degradation within the predator, and invisibility induced by varying surface features

${ }^{*}$ Corresponding author: Agneta.andersson@umu.se (e.g. due to decreased hydrophobicity, negative charge, enzymes and receptors avoiding adherence of the predator) (Gurijala \& Alexander 1990, Pernthaler et al. 1997, Matz \& Jürgens 2003, Jürgens 2007, Corno \& Jürgens 2008, Arnold \& Koudelka 2014).

Bacteria express defense traits to a varying degree depending on the predation pressure experienced within the specific aquatic system. Eutrophic environments have been shown to have a relatively large proportion of inedible bacteria, which could be caused by high predation pressure leading to a higher selection pressure for inedibility (Pernthaler et al. 1997,

() The authors 2016. Open Access under Creative Commons by Attribution Licence. Use, distribution and reproduction are unrestricted. Authors and original publication must be credited. 
Bohannan \& Lenski 2000b, Auer et al. 2004, Corno \& Jürgens 2008, Hall et al. 2008). The selection for inedibility may occur at the community level as well as at the species level, influencing phenotypic expressions (plasticity or rapid adaptation) or causing genetic alterations (rapid evolution).

Depending on nutrient availability in the aquatic system, the evolutionary selection forces can differ (Bohannan \& Lenski 2000a). Lopez Pascua et al. (2014) showed in a host-parasite system that high resource availability can cause a decrease of the fluctuating selection dynamics. Instead a nutrient rich environment leads to 'arms race' dynamics, resulting in the evolution of predation resistant prey. In nutrient poor conditions, when population sizes are lower, energy demanding defense traits and lower predation pressure make it relatively more costly to resist predation (Bohannan \& Lenski 2000a, Lopez Pascua et al. 2014). Fluctuating selection dynamics lead to large variations in bottom-up and top-down control of bacteria in aquatic systems (Kalinowska et al. 2013), and thus the occurrence of advantageous bacterial ecotypes differs over time. Bacteria that possess defense mechanisms and preparedness towards predators therefore exist in all types of aquatic systems. Even in environments with constant nutrient availability and temperature, there are shifts in the magnitude of bottom-up and top-down forces due to predator-prey interactions (Andersson et al. 1986). This suggests that defense mechanisms in bacterial communities should be diverse, inducible or highly adaptable to varying predation pressure.

In an experimental study, Pernthaler et al. (1997) observed that 2 different defense strategies cooccurred in a bacterial community: bacteria that formed elongated filaments that were inactive (i.e. low growth rate) and bacteria that increased the growth rate to 'outgrow' the predators. Thus, there may be different bacterial strategies in the same habitat to achieve predation resistance: (1) fast-growing bacteria which are vulnerable to predation, but may outgrow their predators; (2) phenotypically plastic bacteria, where predation resistance traits can be induced if the predation pressure on bacteria is high, which is accompanied by energetic costs (Yoshida et al. 2004, Whitman \& Agrawal 2009); (3) constitutively expressed predation resistant traits, where predation resistant traits occur independently of environmental signals. Due to heterogeneity in the aquatic environment, there may be niches which allow for coexistence of bacteria with different defense strategies and plasticity traits. However, although it is well known that the predation pressure on bacteria shows large temporal and spatial variations in aquatic environments (Andersson et al. 1986, Jürgens \& Matz 2002, Thelaus et al. 2008b), the adaptability of predation resistance in different bacteria is still poorly understood. A recent study showed that, despite variation in predation pressure, the bacterial community composition did not vary significantly, indicating that bacteria were resilient to changes in protist predation pressure (Baltar et al. 2016). Nevertheless, variation in predation resistance adaptation may be a mechanism for ecological niche differentiation among varying bacterial groups (Salcher 2014), but also a means of creating resilience or resistance in bacterial communities to predation disturbances.

The aim of this study was to elucidate if bacteria isolated from a homogeneous seawater enclosure have different predation resistance properties and potential for adaptation, i.e. plasticity or rapid evolution. The seawater enclosure had constant temperature and flow through of nutrients. Organisms present in the enclosure experiment were bacteria, heterotrophic nanoflagellates (HNF), dinoflagellates and ciliates. The predation pressure on the bacteria and the bacterial community composition varied considerably over time. After running the experiment for more than $2 \mathrm{mo}$, bacteria were isolated and tested for predation resistance and potential for adaptation using a standardized edibility test by a ciliate. We hypothesized that alterations in predation resistance, i.e. changes in the mortality rate of the bacteria due to predation by a ciliate, would be common among the isolated bacteria. Rapid adaptation in predation resistance may be an important mechanism making the bacterial community resilient or even resistant to a varying predation pressure.

\section{MATERIALS AND METHODS}

\section{Seawater microcosm experiment}

Seawater was collected during the summer season (July) from $1.5 \mathrm{~m}$ depth at a coastal station in the northern Baltic Sea $\left(63^{\circ} 34^{\prime} \mathrm{N}, 19^{\circ} 54^{\prime} \mathrm{E}\right)$ using a Ruttner sampler. The water temperature was $20^{\circ} \mathrm{C}$ and the salinity 3.9. For each microcosm in a triplicate experiment, $900 \mathrm{ml}$ of $0.2 \mu \mathrm{m}$-filtered seawater was inoculated with $100 \mathrm{ml}$ of $100 \mu \mathrm{m}$-filtered seawater in 21 Erlenmeyer flasks. The microcosms were incubated in the dark at $20^{\circ} \mathrm{C}$ temperature over $55 \mathrm{~d}$. The pre-filtration of the inoculum was made in order to exclude mesozooplankton. To maintain microbial production over time, nutrients were added and each 
day $10 \%$ of the water was exchanged with $0.2 \mu \mathrm{m}$ filtered autoclaved seawater. A daily nutrient addition was made; glucose $\left(\mathrm{C}_{6} \mathrm{H}_{12} \mathrm{O}_{6}\right) 1 \mu \mathrm{mol} \mathrm{l}^{-1}$, ammonium $\left(\mathrm{NH}_{4} \mathrm{Cl}\right) 0.295 \mu \mathrm{mol} \mathrm{l}^{-1}$ and phosphate $\left(\mathrm{NaPO}_{4}\right)$ $0.02 \mu \mathrm{mol} \mathrm{l}^{-1}$.

The microcosms were sampled twice a week. Heterotrophic bacteria and heterotrophic nanoflagellate (HNF) samples were preserved with glutaraldehyde ( $4 \%$ final concentration), and samples for ciliate counting were preserved with alkaline Lugol's solution ( $0.2 \%$ final concentration). To enumerate bacteria, the preserved samples were filtered onto $0.2 \mu \mathrm{m}$ black polycarbonate filters, stained with acridine orange and counted with an epifluorescence microscope at 1000x magnification (Nikon Eclipse TE 2000) (Hobbie et al. 1977). Bacterial cell volumes were determined using the image analysis program LabMicrobe, BioRas (Blackburn et al. 1998), and carbon biomass was calculated as in Eriksson-Wiklund et al. (2009). HNF were filtered onto $0.6 \mu \mathrm{m}$ black polycarbonate filters, stained with proflavin $(2 \%$ final concentration) and measured and counted microscopically (Sherr et al. 1993). At least 1 diagonal of the filter area was counted. For enumeration of ciliates, $50 \mathrm{ml}$ fixed samples were settled in sedimentation chambers for at least $40 \mathrm{~h}$. Four diagonals or the whole chamber area was counted and measured. On average 200 cells per sample were counted. Carbon biomasses for HNF and other protozoa were calculated according to Menden-Deuer \& Lessard (2000). Predation pressure on bacteria was calculated as the ratio between protozoan and bacterial biomass.

The variation in bacteria, HNF, dinoflagellates, ciliates and protozoan predation pressure over time was analyzed using 1-way ANOVA (IBM SPSS Statistics version 22). Linearity of the data was tested by Q-Q plots. Specific differences were analyzed using Tukey's post hoc test.

\section{Isolation and identification of bacteria}

After running the microcosm experiment for $55 \mathrm{~d}$, two 0.05 to $0.1 \mathrm{ml}$ samples from each flask were spread on Luria agar (LA) plates. Seven different colonies were randomly collected and isolated. To identify the isolates, deoxyribonucleic acid (DNA) was extracted using phenol:chloroform:isoamyl alcohol (25:24:1, pH 8) and subsequent ethanol precipitation steps. Amplification of the $16 \mathrm{~S}$ ribosomal ribonucleic acid (rRNA) gene from bacterial isolates was performed using universal primers F1 and R14, as previously described (Dorsch \& Stackebrandt 1992).
Purified polymerase chain reaction (PCR) products were sequenced using the Quick Start Kit and a CEQ 8800 genetic analysis system (Beckman Coulter). Five good quality sequences (580 to $830 \mathrm{bp}$ ) were deposited in GenBank with accession nos. HM243146 to HM243149 and KP984528. Partial 16S rRNA sequences obtained showed high sequence similarity (>98\%) to Paracoccus sp., Rhizobium sp., Shewanella sp., Rhodobacter sp. and Micrococcus sp. For 2 of the isolates we did not get good quality reads, but they were included in the empirical growth rate studies and edibility tests - here called unidentified species (Unid.) 1 and 2.

\section{Growth characteristics of isolated bacteria}

The growth characteristics of the isolated bacteria were investigated using a rich growth medium (Zobell Marine Broth). For each bacterial isolate, triplicate $50 \mathrm{ml}$ cultures were incubated in $150 \mathrm{ml}$ Erlenmeyer flasks in the dark at room temperature on a shaker. Start concentrations of the bacteria were $\sim 10^{3}$ cells $\mathrm{ml}^{-1}$. Changes in cell abundances were monitored by measuring absorbance $\left(\mathrm{OD}_{750}\right)$ twice a day for 6 to $9 \mathrm{~d}$, using a Jasco V-560 spectro-photometer. The length of the lag phase, the growth rate of the bacteria during exponential growth phase and time for initiation of stationary phase (time from start of the experiment) were observed.

Bacterial growth rate was calculated following Stanier et al. (1976) as:

$$
\text { Growth rate }=\ln 2 g^{-1}
$$

where $g$ is the generation time (doubling time) estimated from the log phase of the growth curve. Average values and standard deviation for the 3 replicates were calculated.

\section{Bacterial community structure}

To analyze changes in the bacterial community structure between the start and the end of the microcosm experiment, $100 \mathrm{ml}$ samples from each incubation flask were filtered onto a $47 \mathrm{~mm}$ polycarbonate filter with a $0.22 \mu \mathrm{m}$ pore size (Poretics, Osmonics) at the start (Day 0) and end (Day 54) of the microcosm experiment. Additionally, 6 of the isolated bacteria (Micrococcus sp., Paracocccus sp., Shewanella sp., Rhizobium sp., Unid. 1 and Unid. 2) were grown over night in Luria broth (LB), and cells were harvested by centrifugation. 
DNA was extracted from filtered microcosm samples and isolated bacteria by using proteinase $\mathrm{K}$, lysozyme, sodium dodecyl sulfate, phenol-chloroform, and a final extraction of ethanol (Massana et al. 1997). The integrity of the extracted DNA was checked by agarose gel electrophoresis and by using a Nanodrop (A260) for nucleic acid concentration. For PCR reactions, the universal $16 \mathrm{~S}$ rRNA primers 341F-GC and 907R targeting eubacteria were used (Muyzer et al. 1993, 1995).

PCR products were analyzed by denaturing gradient gel electrophoresis (DGGE) according to Muyzer \& Smalla (1998) using the DGGE-2001 System (CBS Scientific). Polyacrylamide gels (6\%) were cast (acrylamide:bisacrylamide 37.5:1) with a linear gradient of denaturants from 40 to $80 \%$ (where $100 \%$ is defined as $7 \mathrm{M}$ urea and $40 \%$ deionized formamide). The PCR products were applied to the polyacrylamide gels and run in $1 \times$ Tris-acetate-ethylenediamine tetraacetic acid buffer at $60^{\circ} \mathrm{C}$ for 16 to $18 \mathrm{~h}$ at $100 \mathrm{~V}$. For identification, a mixture of PCR products of the isolated bacteria was loaded on a separate lane. The gels were stained with SYBR Gold (Molecular Probes) and visualized with a Typhoon 9400 Scanner (Amersham Biosciences).

DGGE bands were ordered into a matrix, representing presence or absence of specific operational taxonomic units (OTU) at the start and the end of the experiment. The change in bacterial community composition over time was studied using multi-dimensional scaling (MDS) plots, on the binary transformed DGGE banding patterns. The resemblance matrix based on the Jaccard index was used to create non-metric MDS plots, performed using the package vegan (function 'metaMDS') in the R software environment (R Development Core Team 2013). Permutational multivariate ANOVA (function 'adonis' in the vegan package of $\mathrm{R}$ ) was used to test the effects of time on the bacterial community composition, using the Jaccard distance. Note however, that the nature of permutational tests makes it technically impossible to have a p-value smaller than 0.1 when comparing 2 groups with 3 replicates each. In order to enable the possibility of having a p-value smaller than 0.1 , the number of replicates would need to be increased.

\section{Edibility of isolated bacteria}

To study the edibility of the isolated bacteria and their adaptation for resisting predation, a predation assay was applied (Thelaus et al. 2008a). The axenically grown ciliate Tetrahymena pyriformis (CCAP
1630/1W) was used as predator (Culture Collection of Algae and Protozoa [CCAP], Scottish Association for Marine Science Research Service). This bacterivorous ciliate has a length of $\sim 40 \mu \mathrm{m}$ and has been used in previous studies for testing edibility of different bacterial isolates (e.g. Thelaus et al. 2008a, 2009). The bacteria had average cell size of $\sim 0.2$ to $0.3 \mathrm{um}^{3}$, indicating that they were within the size range for consumption by T. pyriformis (e.g. Thurman et al. 2010).

Six of the bacterial isolates were pre-grown in the dark at room temperature on Luria agar plates to achieve high concentrations. Using a platinum loop, the bacteria were collected and re-suspended in sterile $\mathrm{NaCl}$ solution $(0.9 \%)$. Rhodobacter sp. was difficult to grow on plates and thus pre-grown in LB on a shaker. The culture was concentrated through centrifugation for $10 \mathrm{~min}\left(30000 \times g, 4^{\circ} \mathrm{C}\right)$ and then resuspended as the other strains.

The ciliate, T. pyriformis, was axenically pre-grown in Proteose Pepton yeast (PPY) broth medium at room temperature.

The edibility of each bacterium was tested in 3 replicates. Decreases in bacterial concentrations were analysed by optical density measurements $\left(\mathrm{OD}_{750}\right)$ (Jasco V-560). The edibility test was performed with an initial bacterial concentration of $\sim 5 \times 10^{8} \mathrm{cells} \mathrm{ml}^{-1}$ $\left(\mathrm{OD}_{750}=0.25\right)$ in a volume of $15 \mathrm{ml} \mathrm{NaCl}(0.9 \%)$. At start of the experiment $\sim 200$ ciliate cells $\mathrm{ml}^{-1}$ were added to half the test tubes, the tubes without ciliates served as controls. The tubes were incubated in darkness for $10 \mathrm{~d}$. Optical density $\left(\mathrm{OD}_{750}\right)$ was measured twice a day. Ciliates were quantified twice a day with a Nikon Eclipse TE 2000 inverted microscope at $200 \times$ magnification using a Burker chamber.

At the end of the $10 \mathrm{~d}$ co-incubation, $200 \mu \mathrm{l}$ from each co-incubation was spread on Zobell-plates for re-isolation of bacteria and elimination of ciliates. The edibility assay (bacteria and protozoa co-incubation) was then repeated 3 to 9 times, using ciliates which had not been previously exposed to the tested bacterium. In the cases where contamination was observed on the agar plates, the incubations were stopped.

Calculations of bacterial decline in the co-cultures were performed from Day 1 through to stabilization of bacterial numbers. The slope of the curve $(k)$ was then calculated for each sampling day interval as:

$$
k=-\ln \left(\frac{N_{d a y}}{N_{d a y-1}}\right) / t
$$

where $N$ is the optical density on a given day $\left(N_{\text {day }}\right)$ and the previous day $\left(N_{d a y-1}\right)$, and $t$ is time between 
each sampling (i.e. $24 \mathrm{~h})$. Average $k$-value $\left(k_{a v g}\right)$ for the whole period of decrease was then calculated. Bacterial half-time $\left(T_{1 / 2}\right.$, i.e. inedibility was calculated as:

$$
T_{1 / 2}=\ln 0.5 / k_{a v g}
$$

The bacterial mortality rate (degradation rate) was obtained by inverting $T_{1 / 2}$. The mortality rate of the bacterial isolates at the start and the end (average of 2 final co-culture tests) of the predation experiment was compared.

\section{Adaptation of bacterial grazing resistance}

The bacterial adaptation predation resistance was calculated by comparing the edibility at the start of the experiment (first week of co-culture) with the edibility after exposure to repeatedly high predation as described above. Adaptation was identified when a significant negative slope (linear regression) in the change of mortality rate between the consecutive co-incubations was observed.

\section{RESULTS}

\section{Microbial biomasses and community composition in the microcosm experiment}

The microbial community in the microcosm experiment consisted of bacteria, HNF, the dinoflagellate Gymnodinium sp. and ciliates (dominated by Strobilidium sp.) (Fig. 1). The bacterial biomass varied significantly over time during the experiment (ANOVA, $F=2.69, \mathrm{df}=13, \mathrm{p}=0.014)$. Their biomass doubled during the first week; thereafter, it decreased to $\sim 30 \%$ of the peak value (Fig. 1A; Tukey s post hoc test, $p=0.031$ ). During the last part of the experiment the bacterial biomass was again higher. The average HNF and dinoflagellate biomasses only showed small fluctuations during the experiment (Fig. 1A,B), and their bio- masses did not vary significantly during the experiment (ANOVA, $\mathrm{p}>0.05$ ). The average ciliate biomass showed 2 major peaks (Fig. 1B), which tended to be connected to the maxima of bacterial biomasses. However, due to large variation between the microcosms, significant variations over time could not be shown (ANOVA, p > 0.05). The average predation pressure on bacteria, calculated as the total biomass
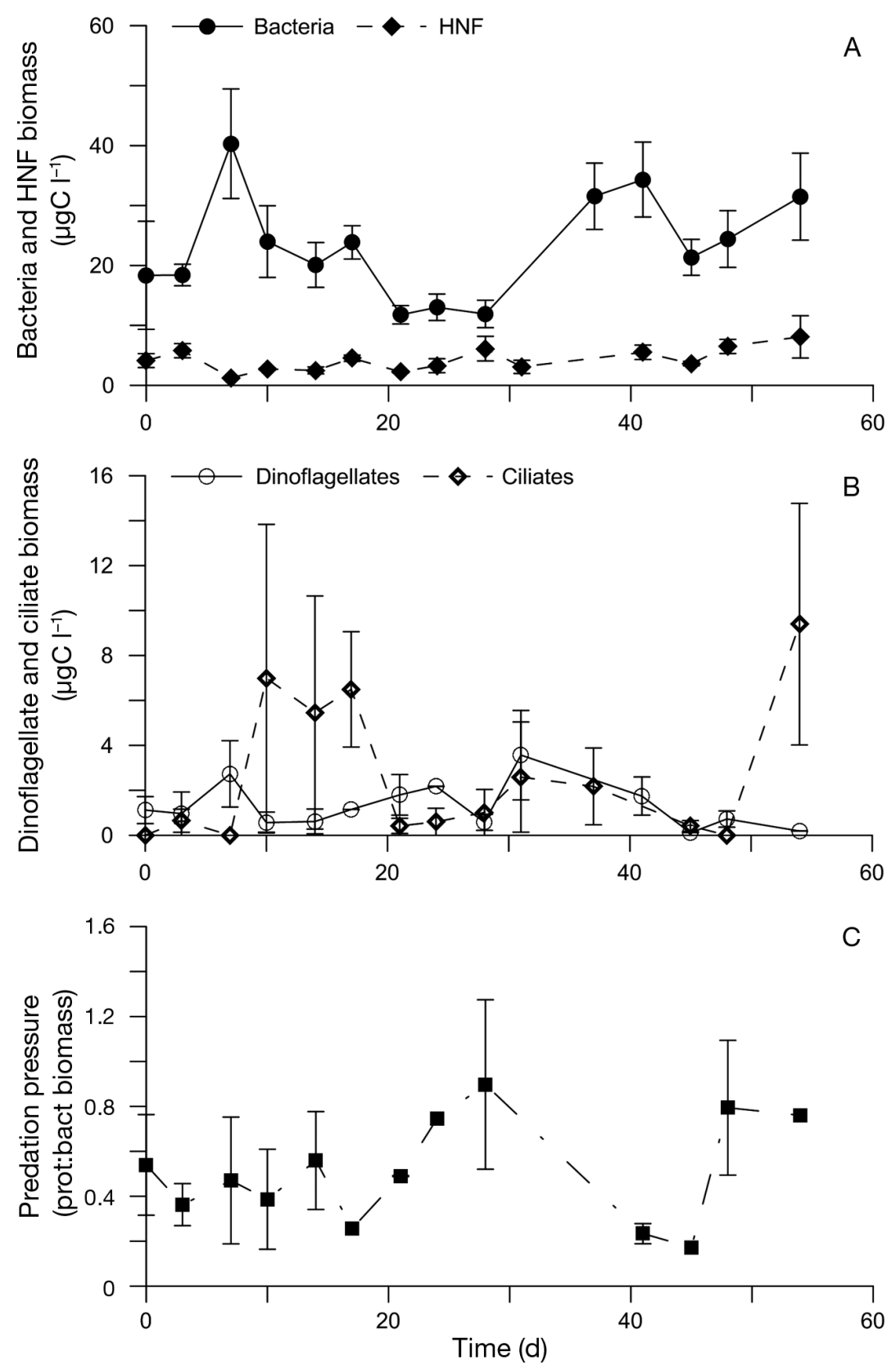

Fig. 1. Carbon biomass concentrations of (A) heterotrophic bacteria vs. heterotrophic nanoflagellates (HNF), and (B) dinoflagellates (Gymnodinium sp.) vs. ciliates (Strombilidium sp.) during the $55 \mathrm{~d}$ microcosm experiment. (C) Predation pressure on bacteria, calculated as total protozoan biomass per bacterial biomass. Bars denote standard deviation of the mean 
of protozoa per bacterial biomass, was highest in the middle and at the end of the experiment (Fig. 1C). On average the protozoan biomass constituted $\sim 50 \%$ of the bacterial biomass; however, the ratio ranged from 14 to $150 \%$. Thus, the predation pressure on bacteria varied $>10$-fold in the experiment, but due to large variations between microcosms significant differences over time could not be shown (ANOVA, p > 0.05).

DGGE analysis of the bacterial community showed a total of 24 OTUs over the time course of the experiment (Table 1). The average number of OTUs was 17 and 10 at the beginning and the end of the microcosm experiment, respectively. The bacterial diversity was thus $\sim 40 \%$ lower at the end of the experiment compared to the start of the experiment. The MDS plot indicated that there were temporal differences in the bacterial community composition (Fig. 2). A permutational ANOVA test based on Jaccard distances gave a p-value of 0.1 , which is the smallest possible $\mathrm{p}$-value that can technically be produced by the permutation test when comparing 2 groups with 3 replicates each.

Table 1. Results of DGGE analysis of the bacterial community at the start and end of a triplicate microcosm experiment. The position of 6 of the isolated bacteria in the DGGE analysis are indicated (Rhodobacter sp. not identified in the DGGE). Unid.: unidentified species; repl.: replicate

\begin{tabular}{|c|c|c|c|c|c|c|c|}
\hline $\begin{array}{l}\text { Position of } \\
\text { isolated bacteria }\end{array}$ & $\begin{array}{l}\text { OTU } \\
\text { no. }\end{array}$ & Repl. 1 & $\begin{array}{l}\text { - Start- } \\
\text { Repl. } 2\end{array}$ & $\overline{\text { Repl. } 3}$ & Repl. 1 & $\begin{array}{l}\text { - End - } \\
\text { Repl. } 2\end{array}$ & $\overline{\text { Repl. } 3}$ \\
\hline \multirow[t]{8}{*}{ Micrococcus sp. } & 1 & 1 & 1 & 1 & 0 & 0 & 0 \\
\hline & 2 & 1 & 1 & 1 & 0 & 0 & 0 \\
\hline & 3 & 1 & 0 & 0 & 1 & 1 & 1 \\
\hline & 4 & 1 & 1 & 1 & 0 & 0 & 1 \\
\hline & 5 & 1 & 1 & 1 & 0 & 0 & 1 \\
\hline & 6 & 1 & 1 & 1 & 0 & 0 & 0 \\
\hline & 7 & 1 & 1 & 1 & 0 & 0 & 0 \\
\hline & 8 & 1 & 1 & 1 & 0 & 1 & 1 \\
\hline Paracoccus sp. & 9 & 1 & 1 & 1 & 1 & 1 & 0 \\
\hline Unid. 1 & 10 & 1 & 1 & 1 & 0 & 0 & 1 \\
\hline \multirow{3}{*}{ Shewanella sp. } & 11 & 1 & 1 & 1 & 1 & 1 & 1 \\
\hline & 12 & 0 & 0 & 0 & 1 & 1 & 1 \\
\hline & 13 & 0 & 0 & 0 & 0 & 0 & 0 \\
\hline Unid. 2 & 14 & 1 & 1 & 1 & 0 & 1 & 0 \\
\hline \multirow[t]{10}{*}{ Rhizobium sp. } & 15 & 0 & 0 & 1 & 0 & 0 & 1 \\
\hline & 16 & 1 & 1 & 0 & 1 & 1 & 1 \\
\hline & 17 & 1 & 1 & 1 & 0 & 0 & 0 \\
\hline & 18 & 1 & 1 & 1 & 0 & 1 & 0 \\
\hline & 19 & 0 & 1 & 1 & 0 & 0 & 0 \\
\hline & 20 & 1 & 1 & 1 & 0 & 0 & 0 \\
\hline & 21 & 1 & 1 & 1 & 1 & 1 & 1 \\
\hline & 22 & 0 & 0 & 0 & 0 & 0 & 0 \\
\hline & 23 & 0 & 0 & 0 & 1 & 0 & 1 \\
\hline & 24 & 0 & 1 & 0 & 0 & 1 & 1 \\
\hline Total OTUs & & 17 & 18 & 17 & 7 & 10 & 12 \\
\hline
\end{tabular}

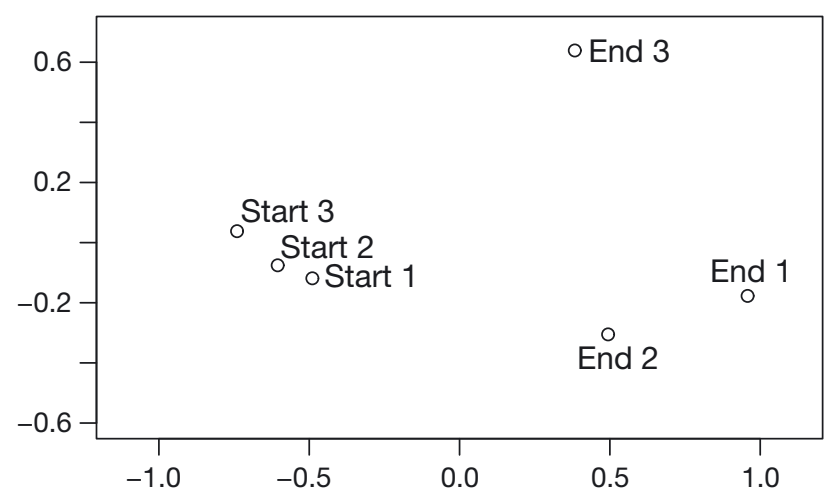

Fig. 2. Multi-dimensional scaling (MDS) plot of bacterial communities from DGGE analysis of 3 replicates at the start and end of the microcosm experiment. The plot is based on the Jaccard distance/index

\section{Characterization of isolated bacteria}

Six out of the 7 bacterial isolates, Micrococcus sp., Paracoccus sp., Shewanella sp., Rhizobium sp., Unid. 1 and Unid. 2, could be identified on most of the DGGE gels (Table 1). Six of the isolated bacteria constituted $\sim 30 \%$ of the total OTUs observed in the DGGE analysis, showing that most isolates were relatively common in the microcosms throughout the experiment. However, Micrococcus sp. was not observed in the DGGE gel at the end the experiment.

The isolated bacteria were further characterized by measuring the lag time, growth rate and stationary phase when grown in a liquid broth medium (Table 2). The lag time showed large variation between isolates, ranging from 2 to $78 \mathrm{~h}$ (Table 2). Furthermore, it was often difficult to initiate growth of Unid. 2 and Rhodobacter $\mathrm{sp}$. The bacterial growth rate and the time for initiation of the stationary phase varied between isolates with a factor of 3 ( 0.08 to $0.27 \mathrm{~h}^{-1}$ and 40 to $130 \mathrm{~h}$, respectively; Table 2).

\section{Edibility and adaption of predation resistance of isolated bacteria}

The initial bacterial edibility (mortality rate), tested immediately after isolation from seawater microcosms, 
Table 2. Growth characteristics of the bacteria grown on liquid broth medium. Means are presented with standard deviation in parentheses. Unid.: unidentified species

\begin{tabular}{|c|c|c|c|c|c|c|c|}
\hline & Micrococcus sp. & Unid. 1 & Paracoccus sp. & Shewanella sp. & Rhizobium sp. & Unid. 2. & Rhodobacter sp \\
\hline Lag time (h) & $2(0)$ & $18(0)$ & $18(0)$ & $2(0)$ & $2(0)$ & $78(21)$ & $18(0)$ \\
\hline Growth rate $\left(\mathrm{h}^{-1}\right)$ & $0.21(0.006)$ & $0.08(0.01)$ & $0.20(0.01)$ & $0.21(0.02)$ & $0.27(0.007)$ & $0.18(0.02)$ & $0.19(0.02)$ \\
\hline $\begin{array}{l}\text { Stationary phase } \\
\text { reached (h) }\end{array}$ & $41(0)$ & $64(0)$ & $70(0)$ & $64(0)$ & $78(8)$ & $131(28)$ & $64(0)$ \\
\hline
\end{tabular}

differed substantially among the 7 isolates (Fig. 3). Micrococcus sp. was the most edible bacterium and Rhodobacter sp. the most inedible, the latter showing equal bacterial numbers regardless of whether ciliates were present or not. The ciliate degraded Micrococcus sp. and Rhodobacter sp. at a rate of 0.06 and $0.009 \mathrm{~h}^{-1}$, respectively, values which correspond to degradation times of 12 and $80 \mathrm{~h}$, respectively. The initial edibility of the other tested bacteria varied from 0.02 to $0.04 \mathrm{~h}^{-1}$. Controls showed that natural mortality accounted for $\sim 20$ to $50 \%$ of the decrease (Micrococcus sp. 32\%, Paracocccus sp. $34 \%$, Shewanella sp. 38\%, Rhizobium sp. $38 \%$, Unid. 1. $53 \%$ and Unid. 2. $45 \%$ ). As Rhodobacter sp. showed equal concentrations in the control and in the treatment with ciliates, the natural mortality was $100 \%$.

The edibility of 5 out of the 7 bacterial isolates decreased over the successive rounds of predationexposure in bacteria and T. pyriformis co-cultures (Figs. 3 \& 4), showing rapid adaptation in bacterial predation resistance. The adaptation towards predation resistance varied between bacterial isolates. Micrococcus sp., Paracoccus sp., Shewanella sp. and Unid. 2 decreased their edibility by 80 to $90 \%$ during the test period, while Unid. 1 overall only showed a slight decrease in edibility. Two of the bacteria were found not to adapt rapidly: we found no decreased edibility for Rhizobium sp., while Rhodobacter sp. was not accepted as a food source.

The predation resistance mechanisms were not investigated in detail; however, cell aggregation of the bacterial cells was observed to occur. For example, when ciliates were added to a culture of the Unid. 2 isolate the bacterial cells immediately aggregated (see photos in the Appendix). Furthermore, Rhodobacter sp. showed a major increase in cell size in some samples, revealing a phenotypic response to predation; however, as Rhodobacter sp. was avoided by the predator from the start of the experiment, this change did not show in the results as a change of edibility.

\section{DISCUSSION}

The results of this study showed that isolated bacteria from a seawater microcosm had varying edibility and differed in adaptive responses to avoid degradation by the ciliate Tetrahymena pyriformis. The varying degree of adaptive predation resistance indicates differences in bacterial life strategies for coping with the varying predation pressure observed in the seawater microcosm. Our results support the hypothesis that different types of predation-resistant bacteria share the same habitat, and that niche differentiation exists (Salcher 2014). The responses to strong predation by the 7 tested bacteria obtained under the same environmental conditions were remarkably different. From the start, the edibility (mortality rate) varied greatly (Figs. $3 \& 4$ ), from being basically inedible (Rhodobacter sp.) to being highly edible (Micrococcus sp.), indicating a wide range of antipredation strategies. Our results are in accordance with previous studies showing coexistence of bacteria utilizing different defense mechanisms in the same habitat (Pernthaler et al. 1997, Matz \& Jürgens 2003, Jürgens 2007). However, as our prolonged edibility test showed, the initial edibility might not reflect the full edibility characteristics of the isolates. The prolonged edibility tests displayed a variety of adaptive responses to repeated exposure to intense predation, and all strains except Rhodobacter sp. and Rhizobium sp. showed different degrees of adaptation to predators (Fig. 4). Micrococcus sp., Paracoccus sp., Shewanella sp., Unid. 2, and Unid 1 were all more edible in the first week compared to the following weeks, but they adapted at different rates to predation until reaching similar levels of inedibility as the Rhodobacter sp. (Fig. 3) by the end of the experiment. Paracoccus sp., Micrococcus sp. and Unid. 2 reached high inedibility and made most of their adaptation in the 2nd co-incubation, while Shewanella sp. made most of its adaptation during the 3rd co-incubation. Shewanella sp. and Unid. 2 also showed slightly lower edibility at the first sampling. It could be argued that Shewanella sp. and Unid. 2 were 

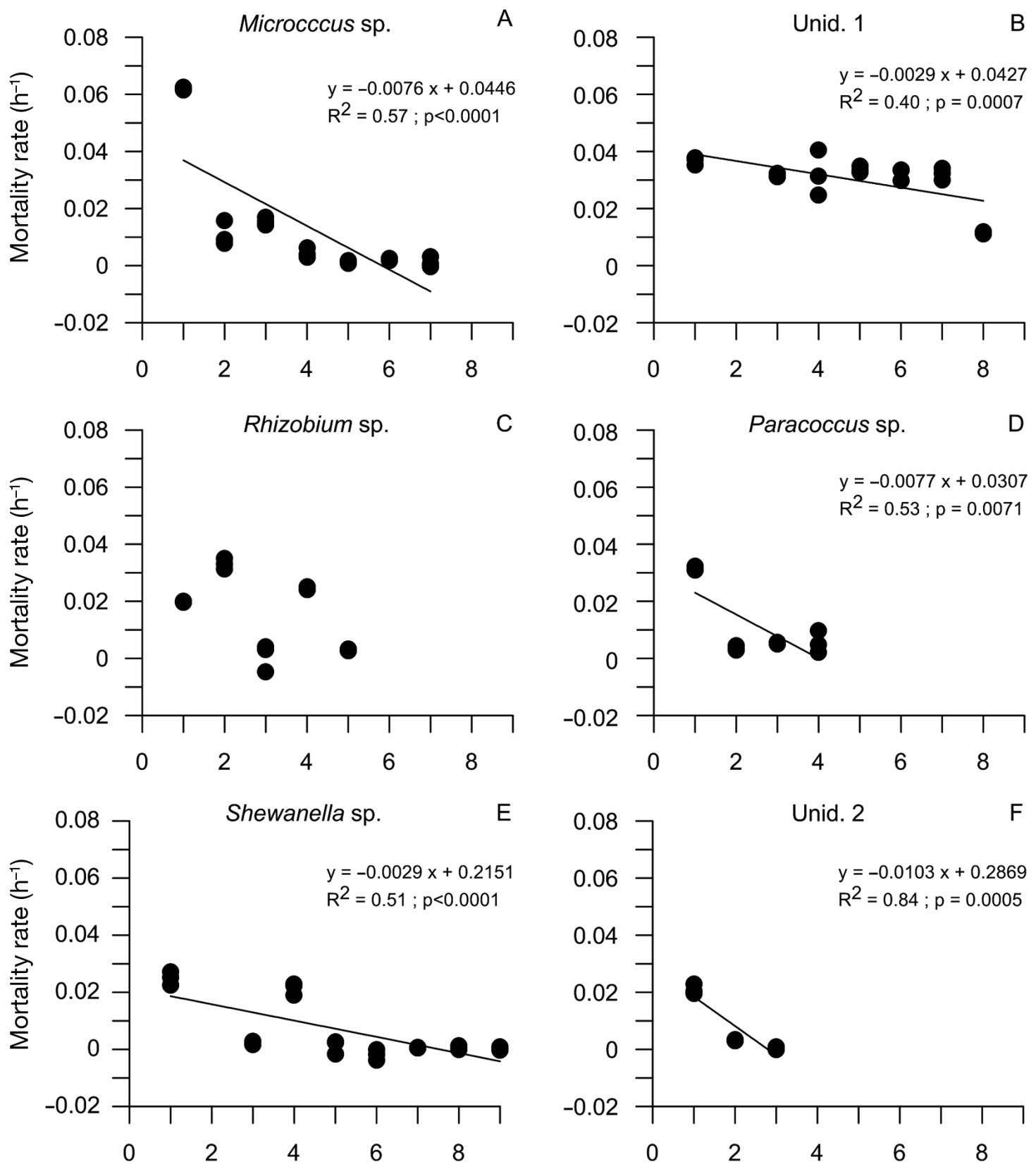

E
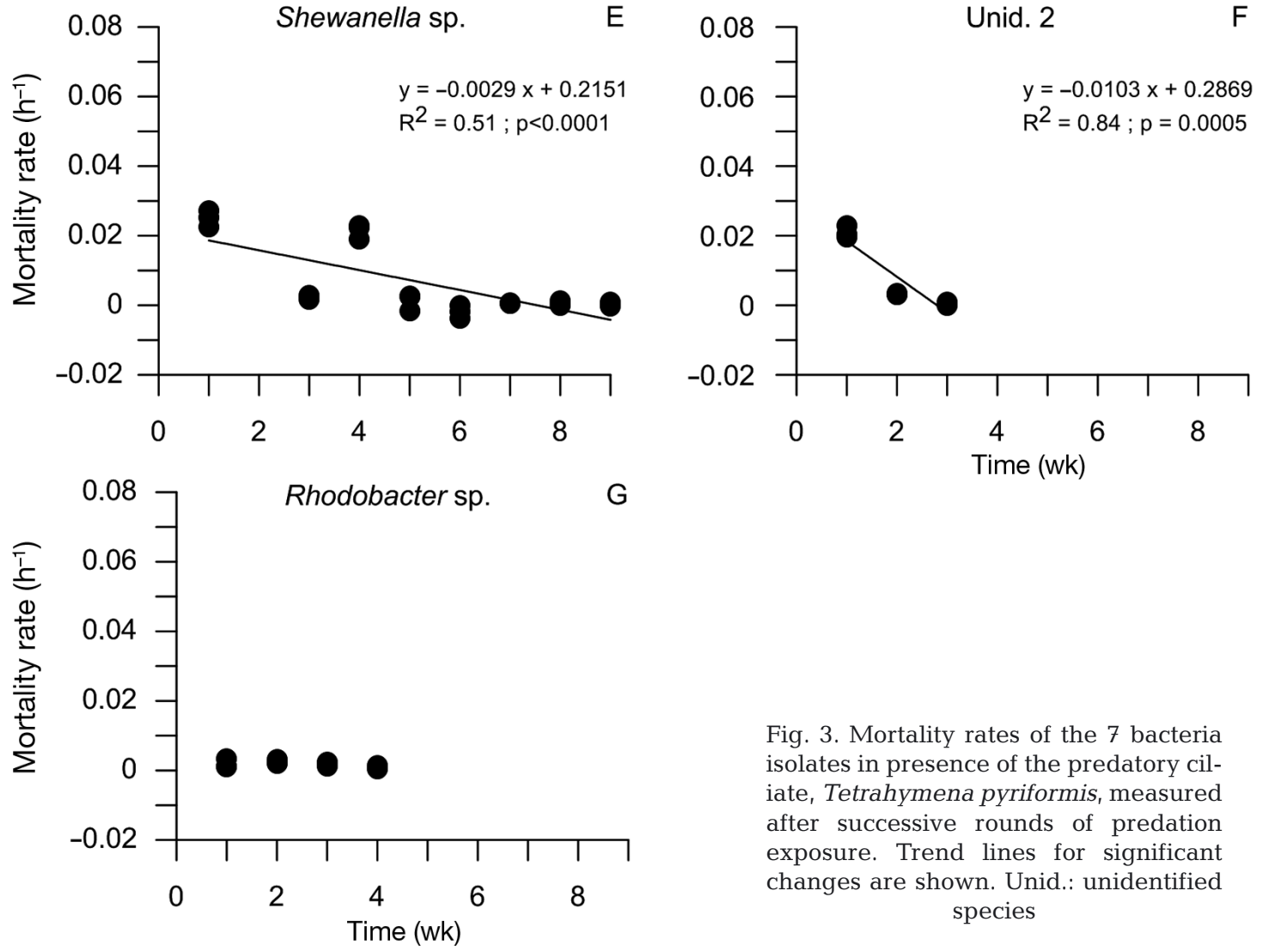

Fig. 3. Mortality rates of the 7 bacteria isolates in presence of the predatory ciliate, Tetrahymena pyriformis, measured after successive rounds of predation exposure. Trend lines for significant changes are shown. Unid.: unidentified species 


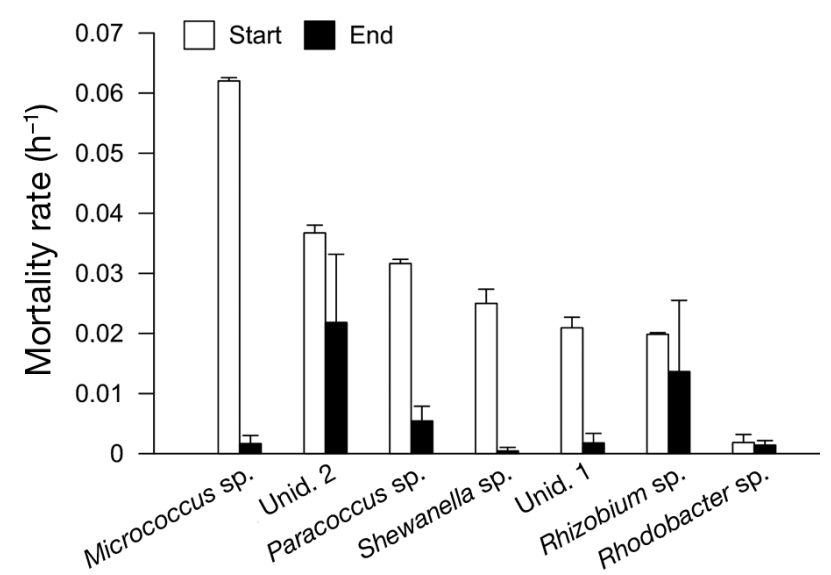

Fig. 4. Mortality rate of the bacterial isolates at the start (white bar) and the end (black bar) of the predation experiment. Error bars denote standard deviation. Unid.: unidentified species

prepared to respond quickly to predation, which would provide a relative advantage during an initial phase of increased predation pressure. These results show how different bacterial predation resisting strategies can co-occur in the same habitat, as also observed by Pernthaler et al. (1997). However, it is not likely that all bacteria are favored by the current conditions in the habitat. Due to the ever-changing composition of biotic and abiotic factors affecting predator-prey cycles within the microcosms as shown in Fig. 1, a bacterial strain favored one day could be disfavored the day after. It is plausible that the bacterial community was preserved during the experiment, but that the ratio between different species varied from time to time. This means that the bacterial community composition does not need to be changed completely in order to adapt to a high and varying predation pressure, rather that the bacterial community is resilient to protozoan grazing disturbance (Baltar et al. 2016).

Even though this study was not designed to identify specific predation defense mechanisms by the bacteria, cell aggregation was obvious for the Unid. 2 bacterium in the presence of ciliates. This is one of the most well documented defense mechanisms within bacteria (Simek et al. 1997, Jürgens et al. 1999, Blom et al. 2010, Jousset 2012). Another common defense mechanism often described in the literature is increase in size (Jürgens 2007), which was observed for Rhodobacter sp. In some of the incubations the Rhodobacter cells increased 3-fold in size. The variable response to predation might be explained by the fact that Rhodobacter sp. possesses a quorum sensing (QS) signaling system. Puskas et al. (1997) found that inactivation of the curl-gene in Rhodobacter sphaero- ides resulted in mucoid colony formation on agar and aggregation in medium. In our experiment, we did not see aggregation, possibly because Rhodobacter sp. was inedible to our predator from the start of the experiment. However, towards the end of the experiment, we did see mucoid colony formation on agar plates indicating use of QS. Further, after spinning Rhodobacter sp. in liquid medium in a centrifuge, we noticed a separation between a brown phase resembling the normal color of the bacterium and a lighter colored mucoid phase, as described in Puskas et al. (1997). Thus, the Rhodobacter sp. seems to have used at least 2 different strategies to avoid predation, based on observations in the present study.

It is likely that the bacterial mortality rates would have been different if a predator other than the ciliate had been used in the predation experiments. In a study by Thelaus et al. (2009), the consumption rates of different bacteria by the same ciliate as used in this study (T. pyriformis) and an interception feeding flagellate (Ochromonas danica) were compared. The ciliate was much more efficient in degrading the bacteria than the flagellate, but the same trend in mortality rate of 'edible' and 'inedible' bacteria, was observed, i.e. the degradation ratio between the edible and the inedible bacteria remained constant, regardless of the predator (Thelaus et al. 2009). We therefore think that the relative change in edibility would have been similar if another bacterivore had been used. On the other hand, with multiple types of predators in a natural environment a trade-off can occur, where the defense against one threat constrains the defense against another (Friman \& Buckling 2013).

The origin of the bacterial strains used in this study, the Baltic Sea, offers an environment with strong seasonality where temperature, light and nutrient availability all change rapidly, and thus also cause rapid shifts in predator-prey cycles (Elmgren 1984, Samuelsson et al. 2006). Rapid shifts in predator-prey cycles were also detected in the microcosm experiment from which the bacteria were isolated (Fig. 1). In such variable environments, the advantage of slowly developing predation resistance might be limited. However, all the bacteria that showed significant adaptation (Micrococcus sp., Shewanella sp., Paracoccus sp. and Unid. 2) during the experiment adapted relatively quickly (in the 2 nd or 3rd coincubations). Since phenotypic plasticity would have occurred in all the co-culture experiments and not only in the first, genetic changes may have been the causative mechanism behind the decreasing mortality rates. An 'arms race' can lead to genetic and functional changes which induce strain diversification 
(Thingstad et al. 2015), while morphological alterations might not be observed.

Studies of 'rapid evolution' would need simultaneous measurements of genetic and environmental changes (Hairston et al. 2005). Since only functional changes were analyzed in the present study, we cannot fully disentangle changes in bacterial mortality rates due to plasticity or evolution. However, the term 'rapid evolution' is used in various ways. Friman et al. (2014) concluded that rapid evolution occurred in Pseudomonas fluorescens, based on observations of adaptation without genetic studies. Rapid evolution might thus have taken place in the present study, especially for the strains subjected to strong selection by the predators over a long period. Each strain was tested for as many rounds of co-incubation as possible until contamination. Due to the contamination, we did not test whether bacteria returned to the original state again if grown without predators. Such a test could possibly have verified whether plasticity or rapid evolution caused the adaptations under predation.

The ciliate $T$. termophila has previously been shown not to evolve during the first month of selection pressure (Meyer \& Kassen 2007, Friman \& Buckling 2013). However, since our experiments were generally longer than a month and we used a different subspecies of Tetrahymena, it was important to spread bacteria on agar plates between co-incubations to eliminate or reduce the number of ciliates to the next co-incubation. For each co-incubation we added ciliates which had not been previously exposed to the tested bacterium. In that way, the arms race between the ciliate and the tested bacterium was reduced in our experiments.

In conclusion, we have used a simple approach to study the response of different bacterial strains, isolated from the same environment, to prolonged repetitive predation. In the initial edibility test, we found a large variation in edibility of the bacteria, indicating niche differentiation. However, when repeatedly exposed to high predation pressure, the bacterial edibility generally decreased. Thus, to fully understand the role of a bacterium in the food web, it may not be enough to study its edibility by a single test, as it will not reveal the possible rapid adaptation of predation resistance. Furthermore, to elucidate whether such changes are due to plasticity or rapid evolution, advanced genetic methods should be applied. Since bacterial communities in natural aquatic systems are exposed to a varying predation pressure, the ecological function of rapid adaptation of predation resistance in these communities may be to be resilient or resistant to predation perturbations.
Acknowledgements. This project was supported by the Swedish Research Council (Project No. 60276201), Umeå Marine Sciences Centre and by the research program ECOCHANGE of the Swedish Research Council (FORMAS) and the Swedish Ministry of Defence (A404215). We thank Dr. J. Berglund, U. Muren and A. Varad for skillful laboratory analyses.

\section{LITERATURE CITED}

Andersson A, Larsson U, Hagström A (1986) Size-selective grazing by a microflagellate on a pelagic bacteria. Mar Ecol Prog Ser 33:51-57

Arnold JW, Koudelka GB (2014) The Trojan horse of the microbiological arms race: Phage-encoded toxins as a defence against eukaryotic predators. Environ Microbiol 16:454-466

Auer B, Elzer U, Arndt H (2004) Comparison of pelagic food webs in lakes along a trophic gradient and with seasonal aspects: Influence of resource and predation. J Plankton Res 26:697-709

Baltar F, Palovaara J, Unrein F, Catala P and others (2016) Marine bacterial community structure resilience to changes in protist predation under phytoplankton bloom conditions. ISME J 10:568-581

Blackburn N, Hagstrom A, Wikner J, Cuadros-Hansson R, Bjornsen PK (1998) Rapid determination of bacterial abundance, biovolume, morphology, and growth by neural network-based image analysis. Appl Environ Microbiol 64:3246-3255

* Blom JF, Horňák K, Šimek K, Pernthaler J (2010) Aggregate formation in a freshwater bacterial strain induced by growth state and conspecific chemical cues. Environ Microbiol 12:2486-2495

Bohannan BJM, Lenski RE (2000a) Linking genetic change to community evolution: insights from studies of bacteria and bacteriophage. Ecol Lett 3:362-377

*Bohannan BJM, Lenski RE (2000b) The relative importance of competition and predation varies with productivity in a model community. Am Nat 156:329-340

* Corno G, Jürgens K (2008) Structural and functional patterns of bacterial communities in response to protist predation along an experimental productivity gradient. Environ Microbiol 10:2857-2871

* Dorsch M, Stackebrandt E (1992) Some modifications in the procedure of direct sequencing of PCR amplified 16srDNA. J Microbiol Methods 16:271-279

Elmgren R (1984) Trophic dynamics in the enclosed, brackish Baltic sea. Rapp P-V Reun Cons Int Explor Mer 183: 152-162

*Eriksson Wiklund AK, Dahlgren K, Sundelin B, Andersson A (2009) Effects of warming and shifts of pelagic food web structure on benthic productivity in a coastal marine system. Mar Ecol Prog Ser 396:13-25

*Friman VP, Buckling A (2013) Effects of predation on realtime host-parasite coevolutionary dynamics. Ecol Lett 16:39-46

Friman VP, Jousset A, Buckling A (2014) Rapid prey evolution can alter the structure of predator-prey communities. J Evol Biol 27:374-380

Gurijala KR, Alexander M (1990) Effect of growth rate and hydrophobicity on bacteria surviving protozoan grazing. Appl Environ Microbiol 56:1631-1635

Hahn MW, Höfle MG (2001) Grazing of protozoa and its 
effect on populations of aquatic bacteria. FEMS Microbiol Ecol 35:113-121

Hairston NG, Ellner SP, Geber MA, Yoshida T, Fox JA (2005) Rapid evolution and the convergence of ecological and evolutionary time. Ecol Lett 8:1114-1127

Hall AR, Meyer JR, Kassen R (2008) Selection for predator resistance varies with resource supply in a model adaptive radiation. Evol Ecol Res 10:735-746

Hobbie JE, Daley RJ, Jasper S (1977) Use of nuclepore filters for counting bacteria by flourescence microscopy. Appl Environ Microbiol 33:1225-1228

Jousset A (2012) Ecological and evolutive implications of bacterial defences against predators. Environ Microbiol 14:1830-1843

Jürgens K (2007) Predation on bacteria and bacterial resistance mechanisms: comparative aspects among different predator groups in aquatic systems. In: Jurkevitch E (ed) Predatory prokaryotes, Vol 4. Springer, Berlin, p 57-92

Jürgens K, Matz C (2002) Predation as a shaping force for the phenotypic and genotypic composition of planktonic bacteria. Antonie van Leeuwenhoek 81:413-434

Jürgens K, Pernthaler J, Schalla S, Amann R (1999) Morphological and compositional changes in a planktonic bacterial community in response to enhanced protozoan grazing. Appl Environ Microbiol 65:1241-1250

Kalinowska K, Gu piel A, Kiersztyn B, Chróst RJ (2013) Factors controlling bacteria and protists in selected mazurian eutrophic lakes (north-eastern poland) during spring. Aquat Biosyst 9:9

Lopez Pascua L, Hall AR, Best A, Morgan AD, Boots M, Buckling A (2014) Higher resources decrease fluctuating selection during host-parasite coevolution. Ecol Lett 17: 1380-1388

Massana R, Murray AE, Preston CM, DeLong EF (1997) Vertical distribution and phylogenetic characterization of marine planktonic Archaea in the Santa Barbara channel. Appl Environ Microbiol 63:50-56

Matz C, Jürgens K (2003) Interaction of nutrient limitation and protozoan grazing determines the phenotypic structure of a bacterial community. Microb Ecol 45:384-398

Menden-Deuer S, Lessard EJ (2000) Carbon to volume relationships for dinoflagellates, diatoms, and other protist plankton. Limnol Oceanogr 45:569-579

Meyer JR, Kassen R (2007) The effects of competition and predation on diversification in a model adaptive radiation. Nature 446:432-435

Muyzer G, Smalla K (1998) Application of denaturing gradient gel electrophoresis (DGGE) and temperature gradient gel electrophoresis (TGGE) in microbial ecology. Antonie van Leeuwenhoek 73:127-141

Muyzer G, de Waal EC, Uitterlinden AG (1993) Profiling of complex microbial populations by denaturing gradient gel electrophoresis analysis of polymerase chain reaction-amplified genes coding for 16s rRNA. Appl Environ Microbiol 59:695-700

Muyzer G, Teske A, Wirsen CO, Jannasch HW (1995) Phylogenetic relationships of Thiomicrospira species and their identification in deep-sea hydrothermal vent samples by denaturing gradient gel electrophoresis of $16 \mathrm{~s}$ rDNA fragments. Arch Microbiol 164:165-172

Pernthaler J, Posch T, Šimek K, Vrba J, Amann R, Psenner R (1997) Contrasting bacterial strategies to coexist with a flagellate predator in an experimental microbial assemblage. Appl Environ Microbiol 63:596-601

*Puskas A, Greenberg EP, Kaplan S, Schaefer AL (1997) A quorum-sensing system in the free-living photosynthetic bacterium Rhodobacter sphaeroides. J Bacteriol 179: 7530-7537

R Development Core Team (2013) R: a language and environment for statistical computing. $\mathrm{R}$ Foundation for Statistical Computing, Vienna

Salcher MM (2014) Same but different: ecological niche partitioning of planktonic freshwater prokaryotes. J Limnol 73:74-87

Samuelsson K, Berglund J, Andersson A (2006) Factors structuring the heterotrophic flagellate and ciliate community along a brackish water primary production gradient. J Plankton Res 28:345-359

Sherr EB, Caron DA, Sherr BF (1993) Staining of heterotrophic protists for visualization via epifluorescence microscopy. In: Kemp B et al. (eds) Handbook of methods in aquatic microbial ecology. Lewis, New York, NY, p 213-228

خ Šimek K, Vrba J, Pernthaler J, Posch T, Hartman P, Nedoma J, Psenner R (1997) Morphological and compositional shifts in an experimental bacterial community influenced by protists with contrasting feeding modes. Appl Environ Microbiol 63:587-595

Stanier RY, Adelberg EA, Ingraham JL (1976) General microbiology, 4th edn. Macmillan, London

Thelaus J, Forsman M, Andersson A (2008a) Role of productivity and protozoan abundance for the occurrence of predation-resistant bacteria in aquatic systems. Microb Ecol 56:18-28

* Thelaus J, Haecky P, Forsman M, Andersson A (2008b) Predation pressure on bacteria increases along aquatic productivity gradients. Aquat Microb Ecol 52:45-55

*Thelaus J, Andersson A, Mathisen P, Forslund A-L, Forsman M (2009) Influence of nutrient status and grazing pressure on the fate of Francisella tularensis in lake water. FEMS Microb Ecol 67:69-80

* Thingstad TF, Pree B, Giske J, Vage S (2015) What difference does it make if viruses are strain- rather than species-specific? Front Microbiol 6:320

* Thurman J, Parry JD, Hill PJ, Laybourn-Parry J (2010) The filter-feeding ciliates Colpidium striatum and Tetrahymena pyriformis display selective feeding behaviours in the presence of mixed, equally-sized, bacterial prey. Protist 161:577-588

*Weinbauer MG (2004) Ecology of prokaryotic viruses. FEMS Microbiol Rev 28:127-181

Whitman DW, Agrawal AA (2009) What is phenotypic plasticity and why is it important? In: Whitman DW, Ananthakrishnan TN (eds) Phenotypic plasticity of insects. Science Publishers, Boca Raton, FL, p 1-63

Winter C, Bouvier T, Weinbauer MG, Thingstad TF (2010) Trade-offs between competition and defense specialists among unicellular planktonic organisms: the 'killing the winner' hypothesis revisited. Microbiol Mol Biol Rev 74: 42-57

*Yoshida T, Hairston NG, Ellner SP (2004) Evolutionary trade-off between defence against grazing and competitive ability in a simple unicellular alga, Chlorella vulgaris. Proc R Soc B 271:1947-1953 


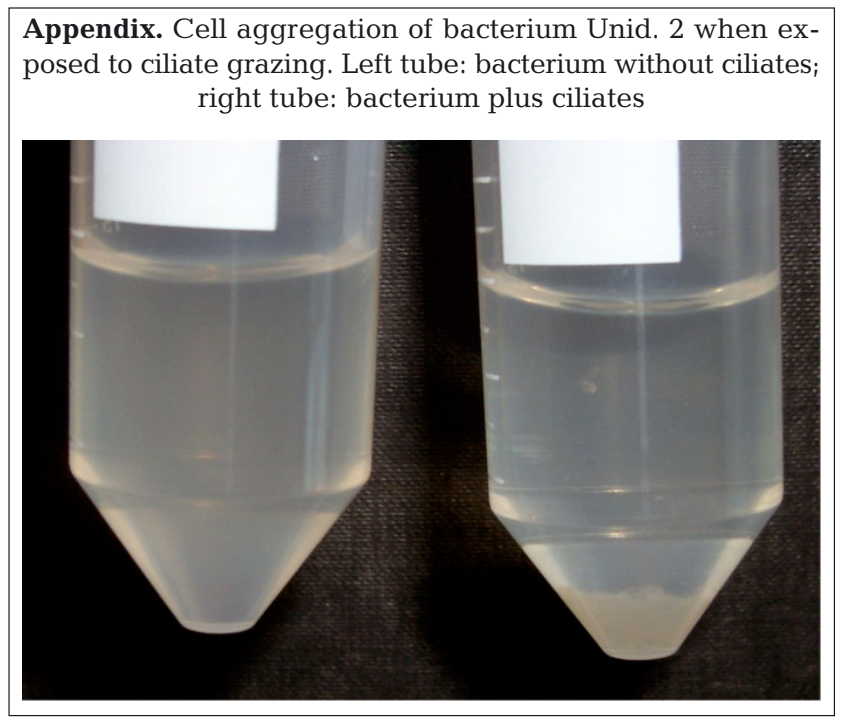

Editorial responsibility: Karel Šimek, České Budějovice, Czech Republic
Submitted: March 2, 2016; Accepted: October 12, 2016 Proofs received from author(s): December 9, 2016 